\title{
Erratum to internal fixation of the proximal tracheal self-expandable metallic stent (SEMS): migration prevention in high risk patients
}

\author{
Editorial Office \\ Journal of Thoracic Disease \\ Correspondence to: Editorial Office. Journal of Thoracic Disease. Email: jtd@amepc.org. \\ Submitted Oct 14, 2021. Accepted for publication Oct 26, 2021. \\ doi: $10.21037 /$ jtd-2021-40 \\ View this article at: https://dx.doi.org/10.21037/jtd-2021-40
}

Erratum to: J Thorac Dis 2020;12:3211-6

In the article that appeared on Page: 3211-3216, Vol 12, No 6 (June 2020) Issue of the Fournal of Thoracic Disease (FTD) (1), an affiliation is missing for Ahmed Ehab. His second affiliation should be:

Chest Medicine Department, Mansoura University, Mansoura, Egypt

Click here to view the updated version of the article.

Open Access Statement: This is an Open Access article distributed in accordance with the Creative Commons AttributionNonCommercial-NoDerivs 4.0 International License (CC BY-NC-ND 4.0), which permits the non-commercial replication and distribution of the article with the strict proviso that no changes or edits are made and the original work is properly cited (including links to both the formal publication through the relevant DOI and the license). See: https://creativecommons.org/licenses/by-nc$\mathrm{nd} / 4.0 \%$.

\section{References}

1. Ehab A, Hagemann M. Internal fixation of the proximal tracheal self-expandable metallic stent (SEMS): migration prevention in high risk patients. J Thorac Dis 2020;12:3211-6.

Cite this article as: Editorial Office. Erratum to internal fixation of the proximal tracheal self-expandable metallic stent (SEMS): migration prevention in high risk patients. J Thorac Dis 2021;13(11):6754. doi: 10.21037/jtd-2021-40 